\title{
Protective Role of Leaf Variegation in Pittosporum tobira under Low Temperature: Insights into the Physio-Biochemical and Molecular Mechanisms
}

\author{
Zhilu Zhang *, Zhonghua Liu, Haina Song, Minghui Chen and Shiping Cheng \\ College of Chemistry and Environmental Engineering, Pingdingshan University, Pingdingshan 467000, China; \\ hphy226@sohu.com (Z.L.); zhanglaoqi1234@sina.com (H.S.), zzl1111@tom.com (M.C.); \\ chengship@163.com (S.C.) \\ * Correspondence: zzl1111@pdsu.edu.cn
}

Received: 9 September 2019; Accepted: 21 September 2019; Published: 30 September 2019

\begin{abstract}
Leaf variegation has been demonstrated to have adaptive functions such as cold tolerance. Pittosporum tobira is an ornamental plant with natural leaf variegated cultivars grown in temperate regions. Herein, we investigated the role of leaf variegation in low temperature responses by comparing variegated "Variegatum" and non-variegated "Green Pittosporum" cultivars. We found that leaf variegation is associated with impaired chloroplast development in the yellow sector, reduced chlorophyll content, strong accumulation of carotenoids and high levels of ROS. However, the photosynthetic efficiency was not obviously impaired in the variegated leaves. Also, leaf variegation plays low temperature protective function since "Variegatum" displayed strong and efficient ROS-scavenging enzymatic systems to buffer cold $\left(10^{\circ} \mathrm{C}\right)$-induced damages. Transcriptome analysis under cold conditions revealed 309 differentially expressed genes between both cultivars. Distinctly, the strong cold response observed in "Variegatum" was essentially attributed to the up-regulation of HSP70/90 genes involved in cellular homeostasis; up-regulation of $P O D$ genes responsible for cell detoxification and up-regulation of $F A D 2$ genes and subsequent down-regulation of GDSL genes leading to high accumulation of polyunsaturated fatty acids for cell membrane fluidity. Overall, our results indicated that leaf variegation is associated with changes in physiological, biochemical and molecular components playing low temperature protective function in P. tobira.
\end{abstract}

Keywords: cold response; Pittosporum tobira; leaf variegation; linoleic acid; ROS scavenging enzyme; heat shock protein

\section{Introduction}

Leaf variegation has been observed in many species of higher plants [1-3] and this special attractive trait has become a focus of plant breeding as it increases the economic value of ornamental plants [4]. There are two categories of leaf variegation in plants: structural-related variegation and pigment-related variegation [5,6]. Two different types of structural variegation have been described, including the air-space type and epidermis type of variegation, which play adaptive roles to varying light conditions [7]. Pigment-leaf variegation is most common in ornamental plants because of the chlorophyll-deficiency [6]. It is marked by the existence of sections that contain abnormal plastids [5]. The leaf color variegation in plants are divided into several types based on color classification for instance green, yellow and albino (white) sectors on leaves $[1,2,8,9]$.

Nuclear and plastid mutations or changes in expression of several genes which contribute to chloroplast biogenesis and chlorophyll biosynthesis induce the leaf variegation [10,11]. The white sectors of variegated leaves lack photosynthetic activity, therefore, leaf variegation may affect 
photosynthetic efficiency [12]. Previously, a transcriptome study of the Arabidopsis white-green variegated mutant immutans (im) and an Arabidopsis FtsH2 mutant line (var2) revealed that the genes related to photosynthesis were down-regulated in the white sectors of leaves $[13,14]$. Furthermore, the chlorophyll-deficient leaf-mutant also showed the expressional repression of transcriptional factors GLK1, Ftsz and MinD that regulate chloroplast development and division [15]. Recently, a mutation in the transcription factor mitochondrial transcription termination factor (mTERF) has been found to induce colorlessness in leaves of variegated fig [3]. Although these studies have provided a deep understanding of the variegation mechanism in plants, the advantage of this trait for the good fitness or for the plant physiology is still poorly understood.

Several potential physiological advantages of variegation have been proposed in plants. For example, it was reported that leaf variegation is involved in plant defense from enemies including aposematic coloration, mimicry of dead or infested plants, masquerade and camouflage [16-19]. It can also play physiological roles such as improved water or gas transport [20], mitigation of UV radiation [21] and thermoregulation [22]. Investigations led on forest trees displaying variegated leaves hinted that the trait might be a strategy to prevent the attack of herbivores [23,24]. Later, studies by Mwafongo et al. [25] on leaf variegation patterns in Ledebouria revoluta highlighted two possible functions including the photoprotection role and the aposematic role. Very recently, Shelef et al. [22] demonstrated that under lower temperatures, variegated wild type Silybum marianum leaves were significantly warmer than all-green mutants, conferring cold stress tolerance. These studies showed that variegation in plants is not just a color mutation but has some physiological advantages.

Pittosporum tobira (Thunb.) Aiton belonging to the family Pittosporaceae originated from East Asia and at present is being widely cultivated as an ornamental flowering plant in temperate and subtropical regions around the world [26]. Typically, P. tobira plants are about 2-3 $\mathrm{m}$ high with thick, rubbery and dark green colored leaves. The fragrant flowers of $P$. tobira have been well studied for their antimicrobial and anti-oxidant activities $[27,28]$. Importantly, some cultivars exhibit leaf variegation with yellowish or creamy white leaf margins and green interior, which have a greater aesthetic appeal and ornamental value compared to the typical all-green $P$. tobira. These particular variegated cultivars are spread to temperate regions. However, besides the aesthetic advantage, the intrinsic physiological importance of leaf variegation for P. tobira is unknown.

In the present work, we studied two P. tobira cultivars namely, "Variegatum" and "Green Pittosporum" with distinct leaf coloration features. To thoroughly understand the role of leaf variegation in P. tobira under cold condition, we investigated the physio-biochemical characteristics at different temperature gradients and profiled leaf transcriptome of the two cultivars under cold stress. Our findings elucidate the leaf variegation mechanism in $P$. tobira and provide novel insights into the thermo-protective function of this important trait.

\section{Results}

\subsection{Characteristics of Variegated Leaves in Pittosporum Tobira}

A naturally occurring leaf variegated cultivar of Pittosporum tobira named "Variegatum" was collected from Pingdingshan, Henan province in China. The cultivar "Variegatum" bears yellowish margins and green interior leaves, whereas, the typical cultivar "Green Pittosporum" exhibits dark green colored leaves (Figure 1). The phenotypic characteristics such as leaf thickness and shape were found to be similar for both cultivars except for the variegation. It is well documented that the leaves of variegated plants having green/yellow sectors have impaired chloroplast biogenesis, less photosynthetic pigments in the yellow sectors and also accumulate excessive levels of reactive oxygen species (ROS) $[29,30]$. To verify these observations in P. tobira, we analyzed the chloroplast ultrastructure in the yellow sector compared to the green sector of the variegated leaf. As shown in Figure 2A,B, the green sector contained well-developed chloroplasts with stacked grana. In contrast, in the white sector of the leaf, plastids did not contain stacked grana but contained large starch 
granules and many plastoglobuli (Figure 2C,D). Next, we assessed the photosynthetic parameters and malonaldehyde (MDA) in both cultivars in August when the ambient temperature is around $20{ }^{\circ} \mathrm{C}$ (Figure 1). The net photosynthetic rate (Pn), the intercellular $\mathrm{CO}_{2}$ concentration $(\mathrm{Ci})$ and the transpiration ( $\mathrm{Tr}$ ) rate were found similar between leaves from both cultivars (Figure 3A-C), showing that the photosynthetic efficiency is not significantly impaired in "Variegatum" as compared to "Green Pittosporum". Next, we compared the content of photosynthesis-related pigments such as total chlorophyll (chlT) and carotenoids (Ca) in both leaf types. The results revealed that the chlT contents were significantly lower $(p<0.05)$ in "Variegatum" compared to the "Green Pittosporum" (Figure 3D), while Ca was higher in "Variegatum" compared to the "Green Pittosporum" (Figure 3E), indicating that the yellowish phenotype in "Variegatum" is underlined by a reduced chlorophyll content and a stronger accumulation of carotenoids. We further measured the MDA content, which is associated with lipid peroxidation via an increased generation of ROS [31]. The MDA was significantly $(p<0.01)$ and highly accumulated in "Variegatum" leaves compared to "Green Pittosporum" leaves (Figure 3F), implying a high level of ROS in the variegated leaves.

Taken together, our results showed that leaf variegation trait in P. tobira is associated with defected chloroplast biogenesis in the yellow sector, reduced chlorophyll content, strong accumulation of carotenoids and high level of ROS.

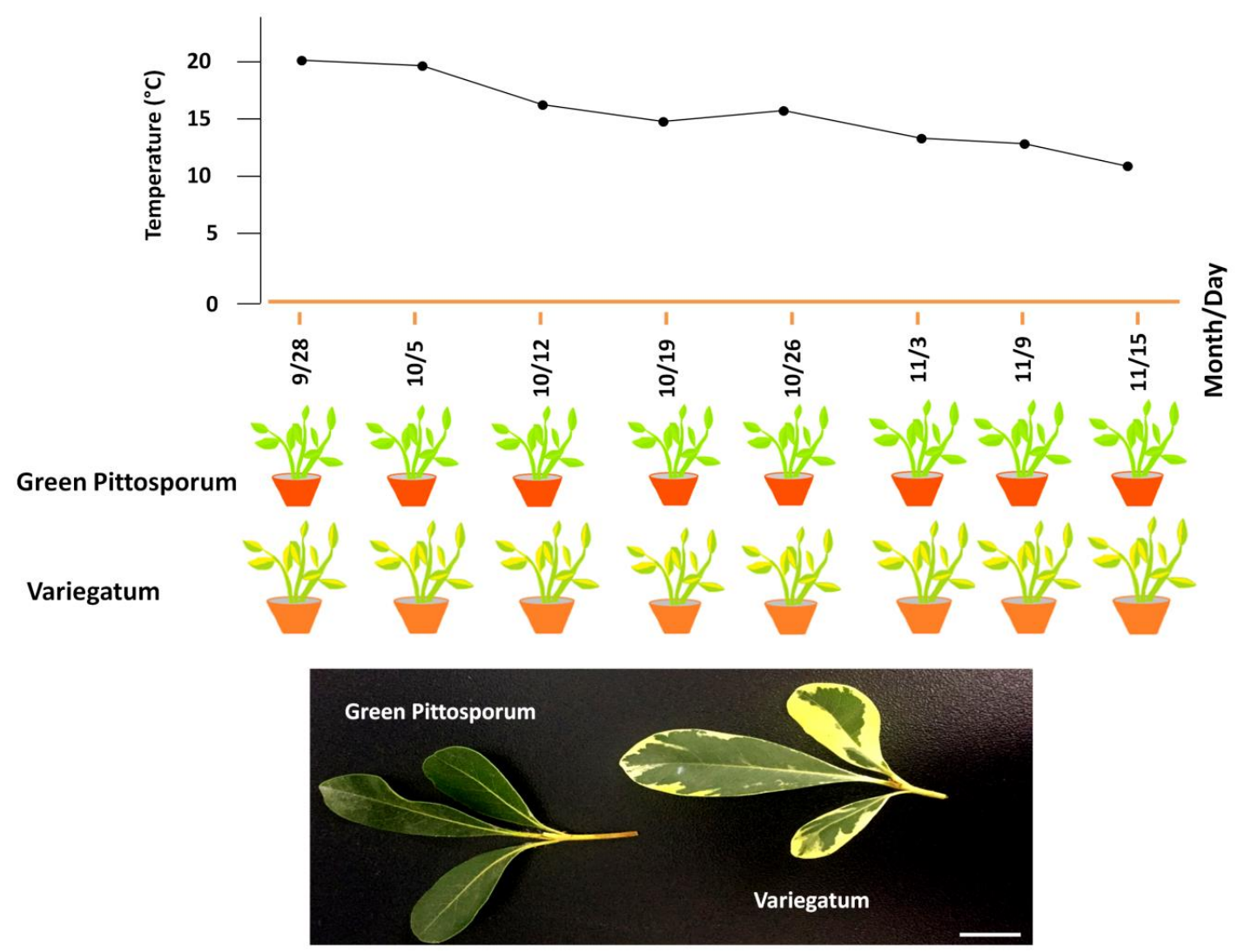

Figure 1. Overview of the experiment design and phenotypes of the two Pittosporum tobira cultivars, namely "Variegatum" with green/yellowish variegated leaf and "Green Pittisporum" with complete dark green leaf. Leaf samples were harvested at different dates following decrease of ambient temperature. The bar $=2 \mathrm{~cm}$. 

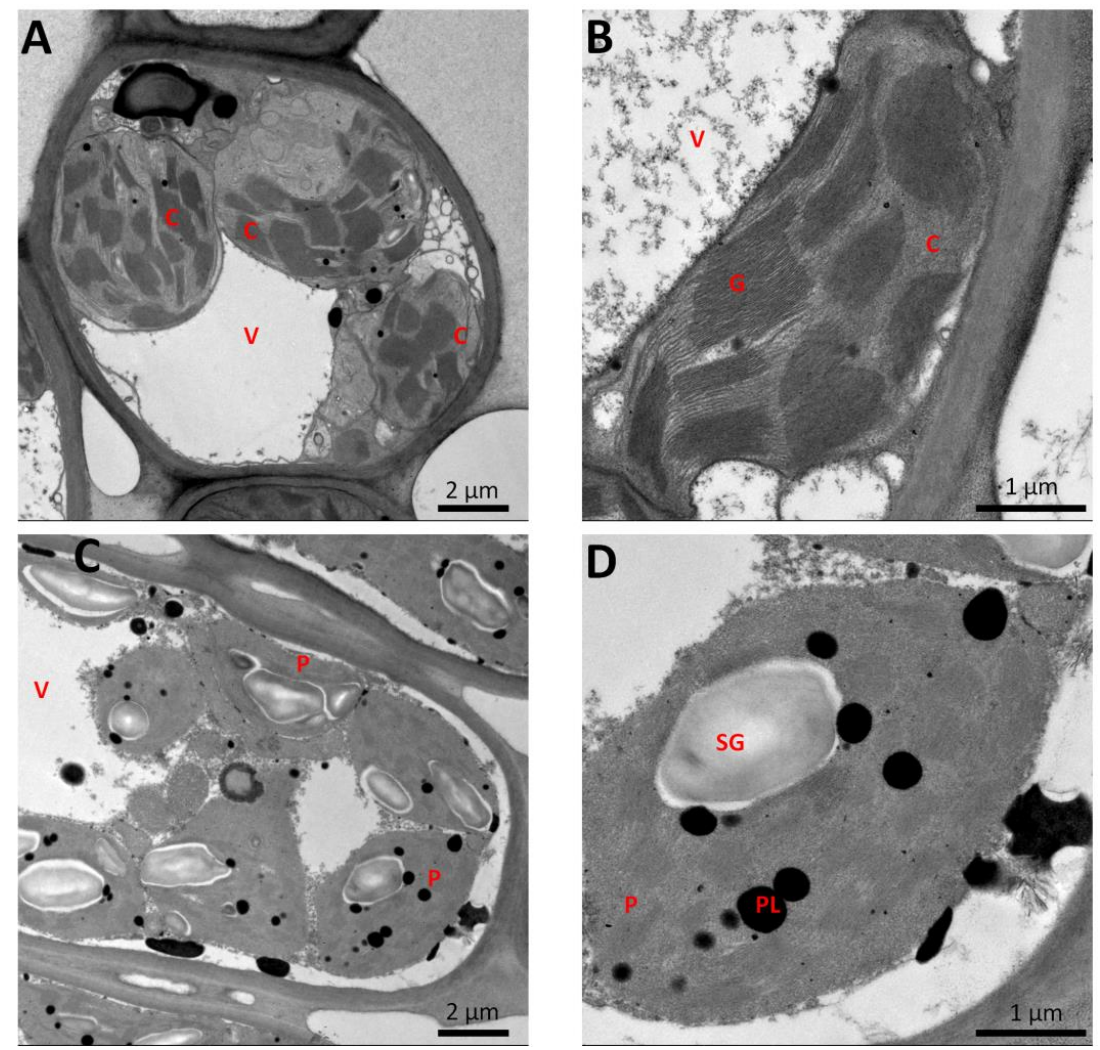

Figure 2. Chloroplast ultrastructure of the green $(\mathbf{A}, \mathbf{B})$ and yellow $(\mathbf{C}, \mathbf{D})$ sectors in variegated leaves of Pittosporum tobira cultivar "Variegatum". C = chloroplast; $\mathrm{P}=$ plastid; SG = starch granule; $\mathrm{G}=$ grana; $\mathrm{V}=$ vacuole, $\mathrm{PL}=$ plastoglobuli.

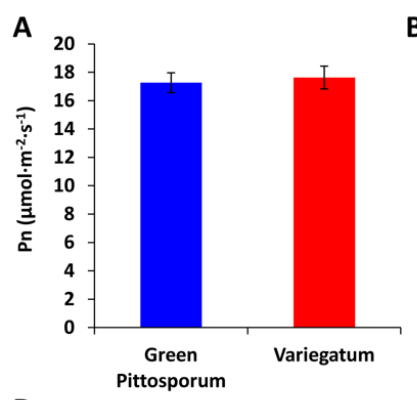

D

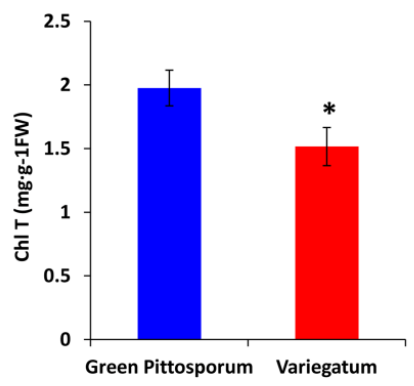

B
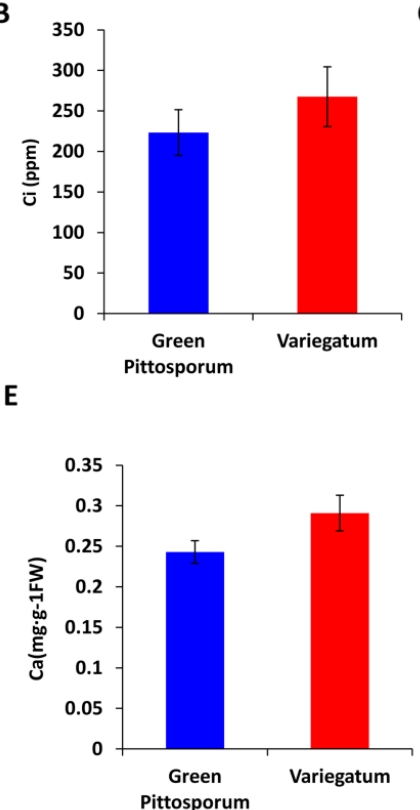
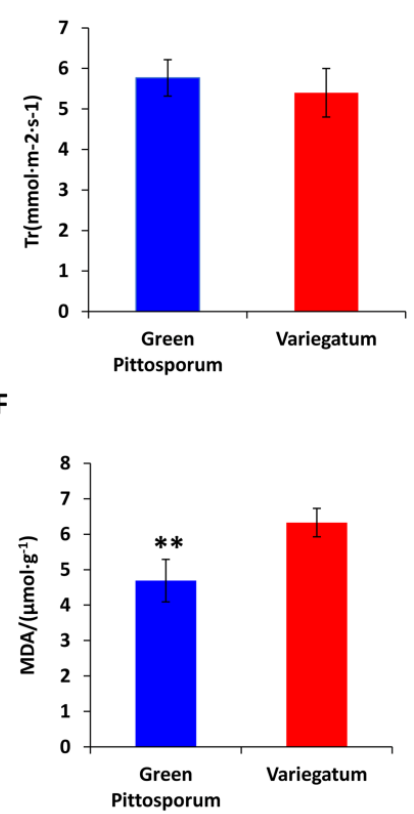

Figure 3. Physio-biochemical comparison of leaf from variegated "Variegatum" and non-variegated "Green Pittosporum" cultivars. (A) net photosynthetic rate $(\mathrm{Pn}),(\mathbf{B})$ intercellular $\mathrm{CO}_{2}$ concentration (Ci), (C) transpiration rate (Tr), (D) total chlorophyll content (ChlT), (E) carotenoids content (Ca) and (F) malonaldehyde content (MDA). ${ }^{*}{ }^{* *}$ above the bars represent significant difference between the two cultivars at $p<0.05$ and $p<0.001$, respectively, using Tukey's honestly significant difference (HSD) test. 


\subsection{Effect of Temperature Decrease on ROS-Scavenging Enzyme Activities in P. tobira Cultivars}

The natural occurrence of leaf variegation in plants suggests that the trait might have adaptive functions [32]. In line with this, we investigated the enzymatic changes with respect to cold stress response in leaves of "Variegatum" and "Green Pittosporum" cultivars over a period of three months (from August to November) when the ambient temperature decreases from optimal condition $\left(20^{\circ} \mathrm{C}\right)$ to cold condition $\left(10^{\circ} \mathrm{C}\right)$. The results showed that the two cultivars respond similarly to the temperature decrease (Figure 4). The activities of all the three ROS-scavenging enzymes including peroxidase (POD), catalase (CAT), superoxide dismutase (SOD), were increased over the assayed period. Notably, $\mathrm{CAT}$ and POD displayed a sharp increase in response to the temperature decrease. At the lowest temperature $\left(10^{\circ} \mathrm{C}\right.$, November $\left.15^{\text {th }}\right)$, POD and CAT activities were significantly higher $(P<0.01)$ in "Variegatum" as compared to "Green Pittosporum" (Figure 4A-C), denoting a stronger response to cold in "Variegatum". We extended the investigation on the MDA contents in both cultivars in order to record the stress levels induced by the temperature decrease. As expected, MDA levels also increased in both cultivars with the temperature decrease, but "Variegatum" seems to suffer less from cold stress. This is evidenced by the significantly higher $(p<0.01)$ MDA in "Green Pittosporum" when the temperature reached $10^{\circ} \mathrm{C}$ (Figure 4D).

Overall, our results indicated that "Variegatum" is endowed with an efficient ROS-scavenging enzymatic system, which is mainly triggered under low temperature. Hence, leaf variegation trait plays a low temperature protective function in P. tobira.

A
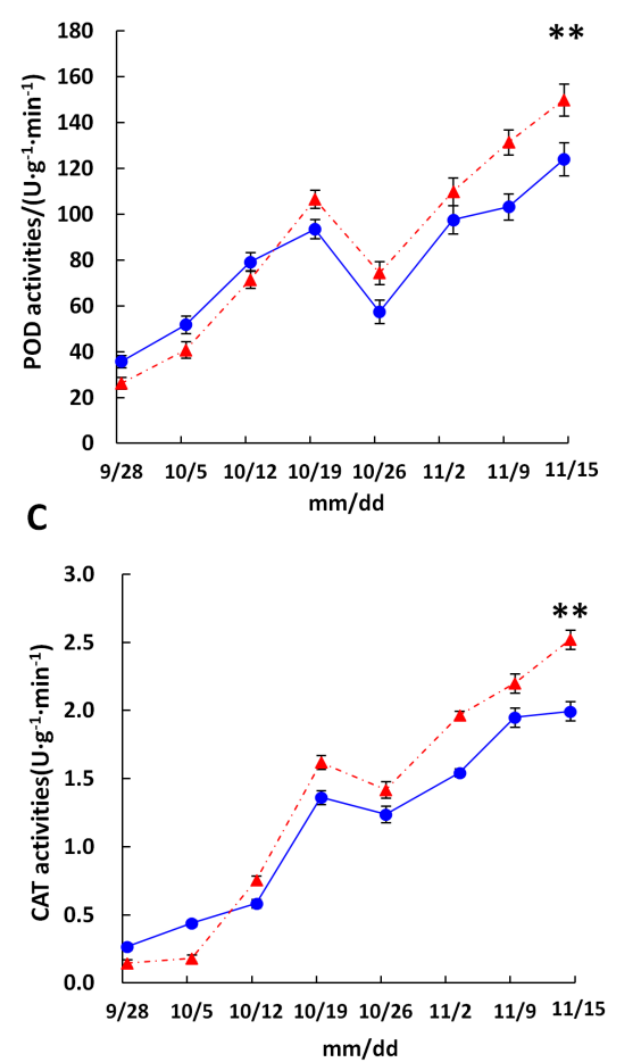

B

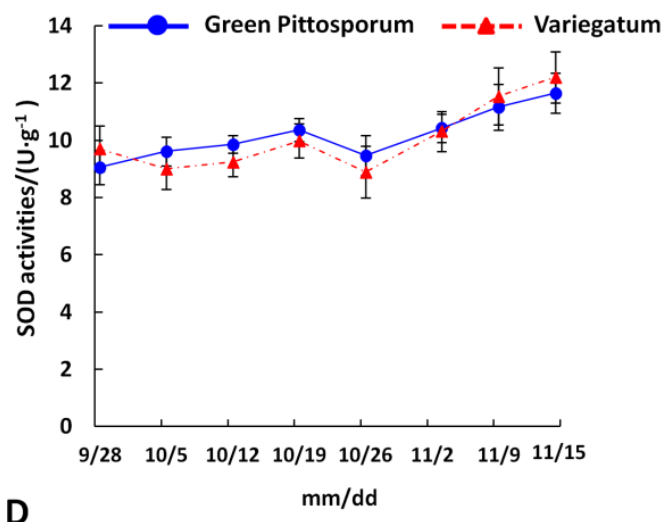

D

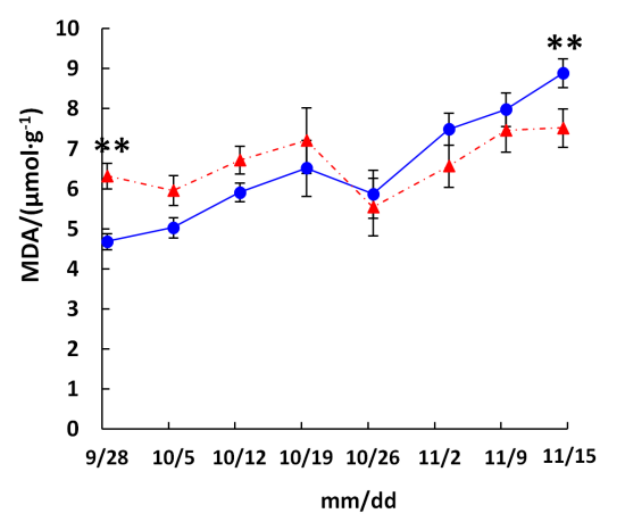

Figure 4. Antioxidant enzymatic activities during temperature decrease. (A) Peroxidase activity (POD), (B) Superoxide dismutase activity (SOD), (C) Catalase activity (CAT), (D) malonaldehyde content (MDA). ${ }^{* *}$ above the lines represents significant difference between the two cultivars at $p<0.001$, using Tukey HSD test. 


\subsection{Transcriptome Sequencing in Leaves of "Variegatum" and "Green Pittosporum" and Functional Annotation of Unigenes}

To get an insight into the molecular pathways and genes conferring the strong response to low temperature in "Variegatum", we synthesized six cDNA libraries from leaves collected from "Variegatum" and "Green Pittosporum" plants under cold conditions $\left(10^{\circ} \mathrm{C}\right)$ and generated de novo RNA-sequencing data for the first time in P. tobira.

The RNA-seq yielded a total of $40.88 \mathrm{~Gb}$ clean data with $92.78 \%$ of bases scoring Q30 and above (Table 1). The assembly was performed using the Trinity software and a total of 112,875 unigenes were obtained with N50 length about 1,017 bp. The assembly integrity was high and specific statistics are shown in Table 2. A total of 51,718 unique genes were functionally annotated based on various databases (Table 3, Table S1). The clean data of each sample was serialized with the assembled unigene libraries and the mapping result statistics are presented in Table 4. Of these genes, 19,677 genes were expressed with the number of fragments per kilobase of exon per million fragments mapped (FPKM) values ranging from 0.04 to 22578.37 (Table S2, Figure 5A).

Hierarchical clustering of the samples based on FPKM showed that all the biological replicates clustered together, suggesting a high reliability of our RNA-sequencing data (Figure 5B). Moreover, a clear separation of the two leaf sample types was observed, implying that a large number of genes may be differentially expressed between the two cultivars to explain the relative stronger response to cold stress in "Variegatum".

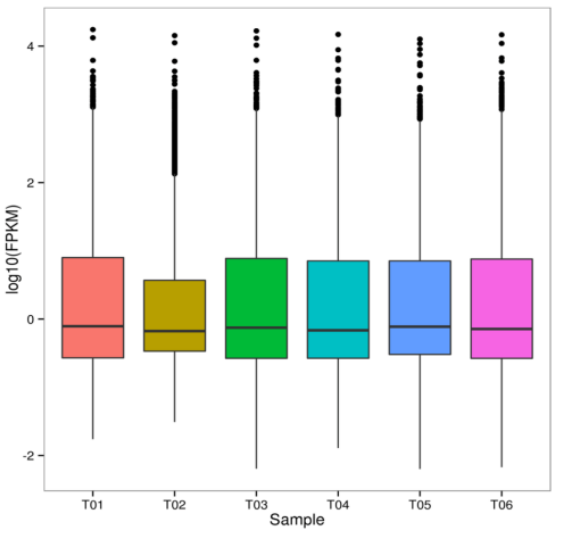

B

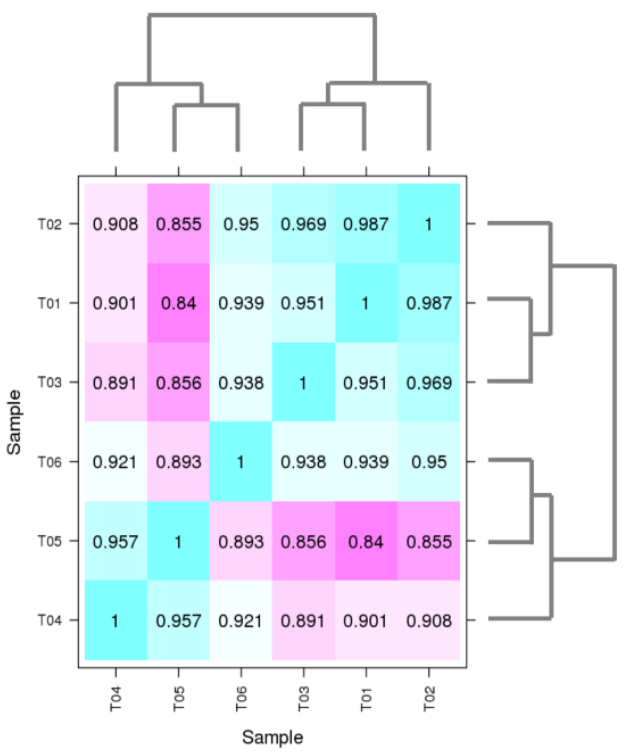

Figure 5. Overview of the transcriptome sequencing. (A) Gene expression profile in the 6 libraries. T01-T03 represent the three replicates libraries of the cultivar "Green Pittosporum" and T04-T06 represent the three replicates libraries of the cultivar "Variegatum". (B) Heatmap clustering showing correlation among $P$. tobira different samples based on global expression profiles. Numbers in the heatmap represent the Pearson correlation value.

Table 1. Overview of the transcriptome sequencing dataset and quality check.

\begin{tabular}{cccccc}
\hline \multicolumn{1}{c}{ Cultivar } & Library-ID & Read Number & Base Number & GC (\%) & \% $\geq$ Q30 \\
\hline "Green Pittosporum" & T01 & $22,115,602$ & $6,612,391,012$ & 45.27 & 92.78 \\
"Green Pittosporum" & T02 & $23,965,370$ & $7,164,119,518$ & 45.01 & 92.97 \\
"Green Pittosporum" & T03 & $22,120,563$ & $6,612,379,716$ & 45.25 & 92.96 \\
"Variegatum" & T04 & $23,413,612$ & $6,996,233,542$ & 44.79 & 93.60 \\
"Variegatum" & T05 & $22,179,179$ & $6,627,936,224$ & 44.64 & 93.36 \\
"Variegatum" & T06 & $22,956,424$ & $6,863,508,574$ & 45.19 & 92.86 \\
\hline
\end{tabular}


Table 2. Statistics of the assembly results.

\begin{tabular}{ccc}
\hline Length Range & Transcript & Unigene \\
\hline $200-300$ & $53,860(25.64 \%)$ & $46,279(41.00 \%)$ \\
$300-500$ & $38,333(18.25 \%)$ & $27,916(24.73 \%)$ \\
$500-1000$ & $38,190(18.18 \%)$ & $20,115(17.82 \%)$ \\
$1000-2000$ & $39,154(18.64 \%)$ & $11,929(10.57 \%)$ \\
2000 & $40,551(19.30 \%)$ & $6,636(5.88 \%)$ \\
Total number & 210,088 & 112,875 \\
Total length (bp) & $241,105,749$ & $72,533,944$ \\
N50 length (bp) & 2,137 & 1,017 \\
Mean length (bp) & 1147.64 & 642.60 \\
\hline
\end{tabular}

Table 3. Functional annotation statistics of the unigenes.

\begin{tabular}{cccc}
\hline \#Anno_Database & Annotated_Number & $\mathbf{3 0 0}<=$ length $<\mathbf{1 0 0 0}$ & Length $>=\mathbf{1 0 0 0}$ \\
\hline COG_Annotation & 17,065 & 6,007 & 6,317 \\
GO_Annotation & 28,283 & 10,378 & 9,062 \\
KEGG_Annotation & 19,595 & 7,857 & 6,277 \\
KOG_Annotation & 30,496 & 11,470 & 10,018 \\
Pfam_Annotation & 33,826 & 12,283 & 13,569 \\
Swissprot_Annotation & 28,074 & 10,455 & 11,043 \\
eggNOG_Annotation & 48,410 & 18,186 & 15,546 \\
nr_Annotation & 47,309 & 17,751 & 15,596 \\
All_Annotated & 51,718 & 19,526 & 15,881 \\
\hline
\end{tabular}

Table 4. Statistics of the mapping of sequencing data with assembly results.

\begin{tabular}{ccccc}
\hline Cultivar & Library-ID & Clean Reads & Mapped Reads & Mapped Ratio \\
\hline “Green Pittosporum" & T01 & $22,115,602$ & $17,518,471$ & $79.21 \%$ \\
"Green Pittosporum" & T02 & $23,965,370$ & $19,005,314$ & $79.30 \%$ \\
"Green Pittosporum" & T03 & $22,120,563$ & $17,599,921$ & $79.56 \%$ \\
"Variegatum" & T04 & $23,413,612$ & $19,153,207$ & $81.80 \%$ \\
“Variegatum" & T05 & $22,179,179$ & $17,804,804$ & $80.28 \%$ \\
"Variegatum" & T06 & $22,956,424$ & $18,290,888$ & $79.68 \%$ \\
\hline
\end{tabular}

2.4. Differential Gene Expression Analysis between "Variegatum" and "Green Pittosporum" under Cold Condition

The differential gene expression analysis was performed on all expressed genes by comparing their expression levels between "Variegatum" and "Green Pittosporum". As shown in Figure 6A, a total of 309 differentially expressed genes (DEG) were obtained, including 156 up-regulated and 153 down-regulated genes in the variegated leaves. To validate our differential expressed gene result, we selected five up-regulated genes and five down-regulated genes (Table S3) and performed qRT-PCR using the cDNAs from leaves of the two cultivars. The qRT-PCR results were strongly correlated with the RNA-seq data $\left(\mathrm{R}^{2}=0.89\right.$, Figure $\left.\mathrm{S} 1\right)$. This result confirms well the high reliability of the RNA-seq data obtained in the present study.

We performed gene ontology (GO) enrichment analysis of these DEGs based on three ontologies: biological process, cellular component and molecular functions. In the biological process components, metabolic and cellular process was found to be the most dominant group (Figure 6B). Within the cellular components, cell and cell part represented the most dominant functional groups. Meanwhile, the catalytic activity and binding were the most abundant functional groups among the molecular functions, showing that enzymes and transcription factors encoding genes may play key roles in the differential cold response. Furthermore, Kyoto Encyclopedia of Genes and Genomes (KEGG) enrichment analysis of the DEGs showed that the biosynthesis of unsaturated fatty acids, sesquiterpenoid and triterpenoid 
biosynthesis, fatty acid metabolism, phenylalanine metabolism and protein processing in endoplasmic reticulum were the main pathways contributed by the DEGs (Figure 6C). The diversity of these molecular pathways highlights the complex mechanism of the improved cold response in relation with leaf variegation in P. tobira.
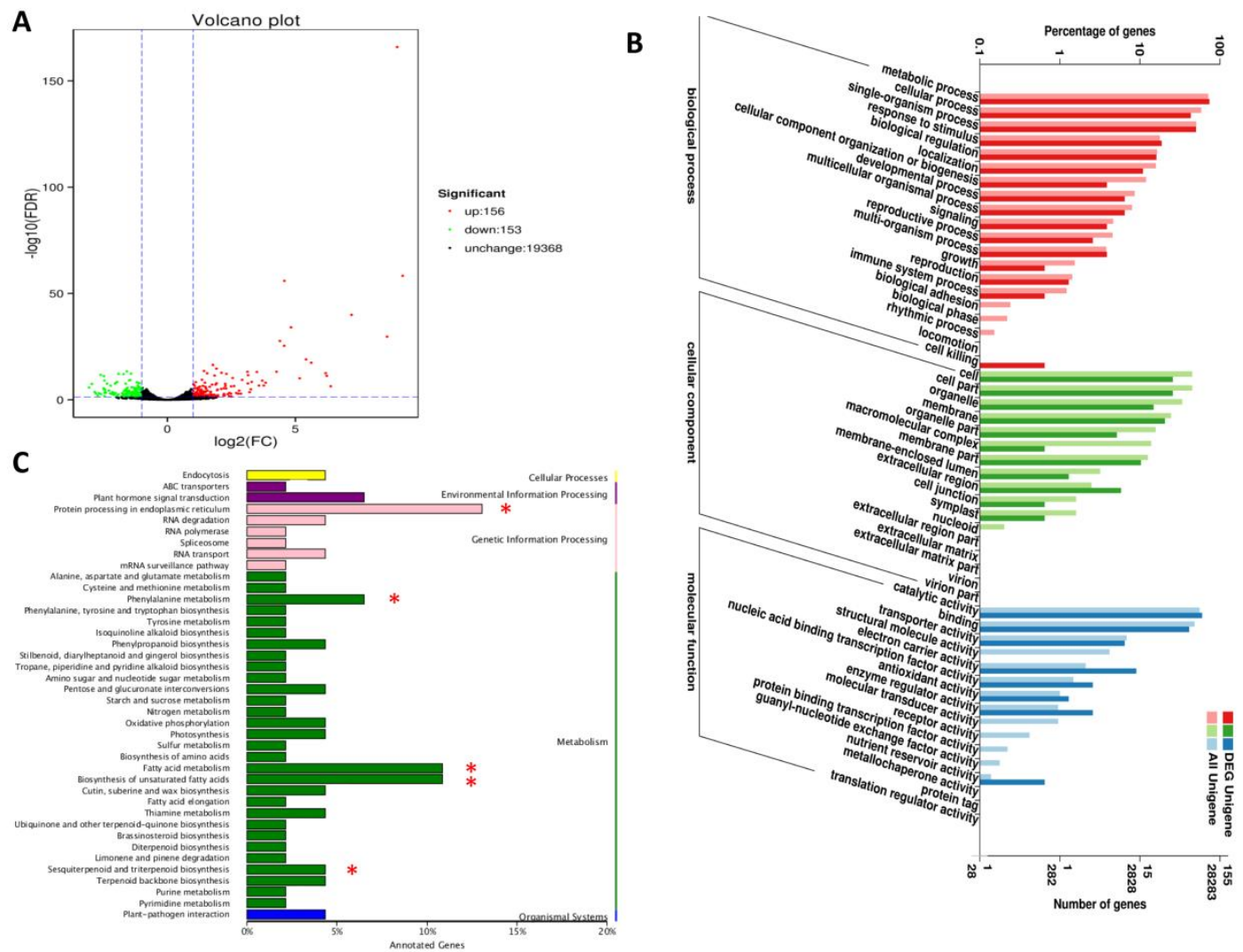

Figure 6. Differentially expressed genes (DEG) analysis between "Green Pittosporum" and "Variegatum". (A) Volcano plot depicting the up-, down- and no- regulated genes between the two cultivars. (B) Gene ontology enrichment analysis of the DEGs. (C) KEGG enrichment analysis of the DEGs. * represent the significantly enriched pathways.

2.5. Major Transcription Factors Differentially Regulated between "Variegatum" and "Green Pittosporum" under Cold Conditions

Since the GO enrichment showed that differential binding activity was important for the cold responses in "Variegatum", we extended our study over the major transcription families (TF) present within the DEGs. In total, 11 down-regulated and 14 up-regulated TFs in "Variegatum" were detected. Among the down-regulated TFs, AP2-ERF, bHLH and MADS-box TFs were enriched (Figure 7A). Distinct TF families were enriched in the up-regulated genes and included NAC, WRKY, HSF and MYB (Figure 7B). Expression fold change of these TFs showed that two NAC genes (c67871.graph_c0 and c63655.graph_c1) were strikingly up-regulated in "Variegatum" (Figure 7C) and may play prominent positive regulatory roles for cold stress endurance. 
A

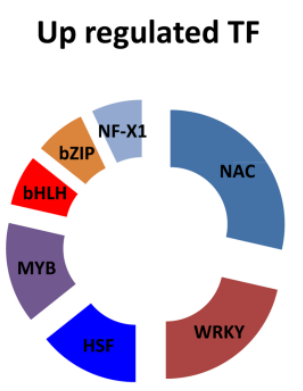

B

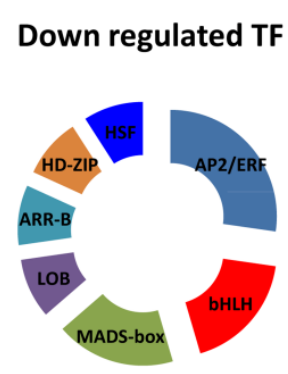

C

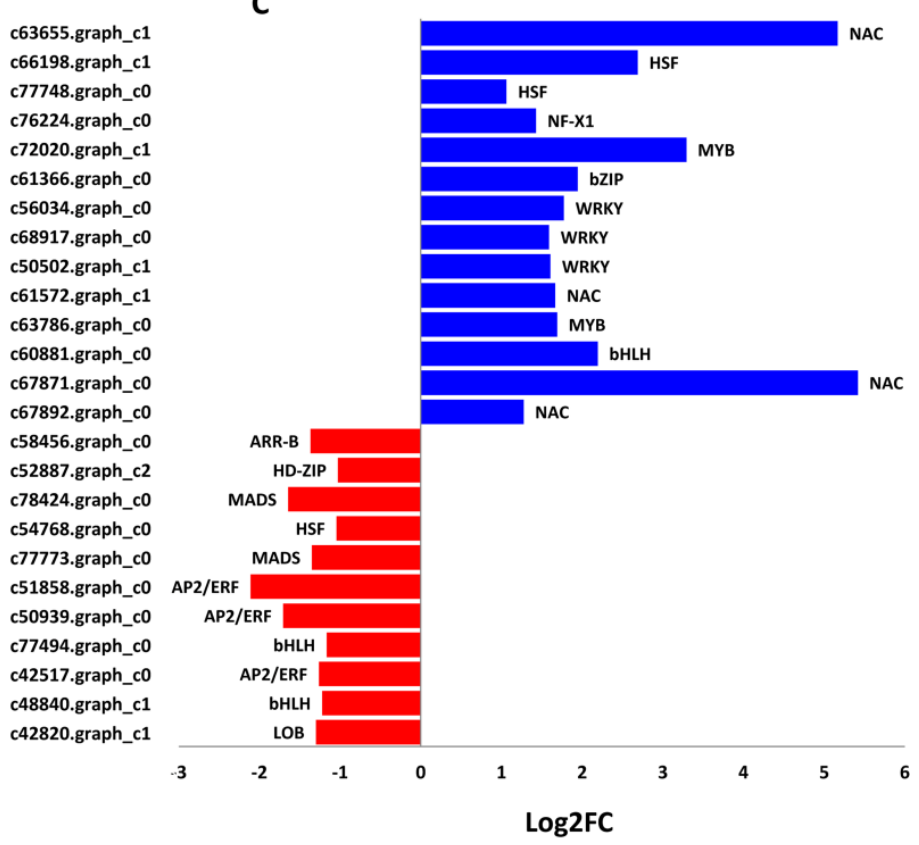

Figure 7. Major transcription factors (TF) families regulating cold response in P. tobira. (A) up-regulated TFs families in "Variegatum", (B) down-regulated TFs families in "Variegatum", (C) Log2 Fold change of the expression of TF genes.

\subsection{DEGs Related to the Biosynthesis of Unsaturated Fatty Acids and Fatty Acids Metabolism}

An increase in polyunsaturated fatty acids has also been reported to play a crucial role in the chilling tolerance of plants [33]. In this study, ten DEGs were mapped to the pathways related to the biosynthesis of unsaturated fatty acids and fatty acids metabolism. Interestingly, all of these DEGs were annotated as endoplasmic reticulum omega- 6 fatty acid desaturase (FAD2) and were all up-regulated in "Variegatum" (Table 5). Since the microsomal enzyme FAD2 principally acts on the desaturation of C18:1 to C18:2 [34], we deduce that "Variegatum" strongly accumulates C18:2 in leaf as a protective molecule under cold conditions. Besides, we also detected nine GDSL-Lipase involved in lipid biosynthesis in plants. All the GDSL genes were down regulated in "Variegatum" (Table 5), suggesting a probable opposite function of GDSL and FAD2 genes during cold endurance in "Variegatum".

Table 5. Key DEGs related to the enriched KEGG pathways involved in the cold responses in variegated P. tobira.

\begin{tabular}{|c|c|c|c|c|}
\hline Pathway & KO & Gene ID & Log2 Fold Change & Gene Description \\
\hline \multicolumn{5}{|c|}{ Phenylalanine metabolism } \\
\hline & K00815 & c55523.graph_c0 & 1.565 & Aminotransferase TAT2 \\
\hline & K00430 & c68309.graph_c0 & 1.057 & Peroxidase \\
\hline & K00430 & c74970.graph_c1 & 1.157 & Peroxidase \\
\hline \multicolumn{5}{|c|}{ Sesquiterpenoid and triterpenoid biosynthesis } \\
\hline & K15472 & c29794.graph_c0 & 1.488 & Premnaspirodiene oxygenase, Cytochrome P450 \\
\hline & K15472 & c43399.graph_c0 & 1.198 & Premnaspirodiene oxygenase, Cytochrome P450 \\
\hline \multicolumn{5}{|c|}{ Biosynthesis of unsaturated fatty acids and fatty acid metabolism } \\
\hline & K10256 & c45880.graph_c0 & 1.973 & FAD2 \\
\hline & K10256 & c72696.graph_c0 & 1.287 & FAD2 \\
\hline & K10256 & c74068.graph_c0 & 1.493 & FAD2 \\
\hline & K10256 & c74296.graph_c0 & 1.385 & FAD2 \\
\hline & K10256 & c75682.graph_c0 & 1.284 & FAD2 \\
\hline & K10256 & c45880.graph_c0 & 1.973 & FAD2 \\
\hline & K10256 & c72696.graph_c0 & 1.287 & FAD2 \\
\hline
\end{tabular}


Table 5. Cont.

\begin{tabular}{|c|c|c|c|c|}
\hline Pathway & KO & Gene ID & Log2 Fold Change & Gene Description \\
\hline & K10256 & c74068.graph_c0 & 1.493 & FAD2 \\
\hline & K10256 & c74296. graph c0 & 1.385 & FAD2 \\
\hline & K10256 & c75682.graph_c0 & 1.284 & FAD2 \\
\hline & -- & c52980.graph_c1 & -1.179 & GDSL \\
\hline & -- & c52915.graph_c0 & -1.582 & GDSL \\
\hline & -- & c62735.graph_c0 & -2.134 & GDSL \\
\hline & -- & c28930.graph_c0 & -1.998 & GDSL \\
\hline & -- & c79198.graph_c0 & -1.068 & GDSL \\
\hline & -- & c63752.graph_c0 & -1.502 & GDSL \\
\hline & -- & c28455.graph_c0 & -1.267 & GDSL \\
\hline & -- & c71358.graph_c0 & -1.635 & GDSL \\
\hline & -- & c76303.graph_c0 & -1.713 & GDSL \\
\hline \multicolumn{5}{|c|}{ Protein processing in endoplasmic reticulum } \\
\hline & K13993 & c55937.graph_c0 & -2.839 & 22.7kDa HSP IV \\
\hline & K13993 & c60091.graph_c0 & -1.125 & 15 kDa HSP \\
\hline & K13993 & c60491.graph_c0 & -1.961 & 17.9 kDa HSP II \\
\hline & K13993 & c70233.graph_c1 & -1.292 & 18.1 kDa HSP I \\
\hline & K04079 & c74041.graph_c0 & 1.283 & 90 kDa HSP \\
\hline & K03283 & c75081.graph_c0 & 1.095 & 70 kDa HSP \\
\hline & K09489 & c68688.graph_c0 & 1.266 & $70 \mathrm{kDa} H S P$ \\
\hline & K03283 & c28616.graph_c1 & 1.018 & $70 \mathrm{kDa} H S P$ \\
\hline & K03283 & c69810.graph_c6 & 1.408 & $70 \mathrm{kDa} H S P$ \\
\hline
\end{tabular}

\subsection{Disturbance of Protein Processing in Endoplasmic Reticulum under Cold Conditions}

The endoplasmic reticulum is a subcellular compartment where proteins and lipids are folded with the help of chaperones. The enrichment of this pathway (Figure 6C) indicates a disturbance of proteins and lipids synthesis under cold conditions. Nine DEGs, all being heat shock proteins (HSP) were detected within this pathway. Notably, we observed that all the small HSP genes (15-22 kDa) were down-regulated while the high molecular weight HSP genes (70-90 kDa) were up-regulated in the variegated leaves (Table 5). This result highlights the weight dependent roles of HSP genes for a stout cold response in variegated P. tobira.

\subsection{DEGs in the Phenylalanine Metabolism}

In this important pathway, we found three DEGs including two POD genes (c68309.graph_c0 and c74970.graph_c1) and c55523.graph_c0 annotated as an aminotransferase TAT2. Interestingly, all these genes were up-regulated in "Variegatum", showing that they contribute positively to the enhanced cold response (Table 5). More importantly, the activation of these genes correlates well with the strong enzymatic activity of POD detected through our biochemical assay in "Variegatum" when the temperature reached $10{ }^{\circ} \mathrm{C}$ (Figure $4 \mathrm{~A}$ ).

\section{Discussion}

\subsection{Characteristics of Leaf Variegation in P. tobira}

Leaf variegated plants have green/white (or yellow) sectors and cells in the green sectors contain normal appearing chloroplasts, while cells in the white sectors have impaired chloroplast biogenesis and lack photosynthetic pigments [12]. Moreover, it has been shown that leaf variegated plants accumulate high levels of ROS $[29,30]$. Although these mechanisms are commonly found in variegated plants, a recent study of the rice $z 3$ mutant leaves showed a new mechanism of variegation, which was caused by an unbalanced distribution of citrate in a transverse pattern in leaf tissues [34]. In our study, we also noted a defected chloroplast development in the yellow sector, reduced chlorophyll content and a high level of ROS in the variegated cultivar (Figures 2 and 3). We also observed an abundance of starch granules in the yellow sector as compared to the green sector, suggesting that the yellow sectors are nutrient sinks because they are unable to perform photosynthesis. Similar 
conclusions were previously reported in different species including variegated Arabidopsis [1,35,36], tobacco [37], begonia [6] and fig [3]. However, the photosynthetic efficiency was not obviously affected in "Variegatum" (Figure 3), contrasting with the reports that leaf variegation affects photosynthetic efficiency [12]. In fact, the yellowish area on "Variegatum" leaves is located on the margin and has a very low surface coverage. So, an explanation to this observation can be that the green part of the leaf is large enough to ensure the photosynthetic activity. Leaf variegation has been attributed to a deficiency or a significant reduction of photosynthetic pigments including carotenoids. In the Arabidopsis white-green variegated mutant immutans (im), an inhibition of carotenoids formation was observed [38]. Similarly, the white section in leaf of variegated Epipremnum aureum contains 10-fold less carotenoids than the green section [39]. In Cyclamen purpurascens, the light green leaf stripes were found with reduced carotenoids and chlorophyll contents [40]. In green/yellow patterns variegated species, similar observations were also noticed in Aucuba japonica [41] and Coleus bluemei [42]. Intriguingly, we observed a higher concentration of carotenoids in the variegated leaves of $P$. tobira as compared to the complete green leaves (Figure 3), a phenomenon which has not yet been reported in variegated plants. Since carotenoids function as accessory light-harvesting pigments, broadening the spectral range over which light can support photosynthesis in plants [43], we deduce that the high carotenoids content in "Variegatum" may compensate the reduced chlorophyll to maintain similar photosynthetic activity as in leaves of "Green Pittosporum".

\subsection{Protective Role of Leaf Variegation in P. tobira under Cold Condition}

The natural occurrence of variegation in plants suggests that the trait might play some adaptive functions beyond their aesthetic value [32]. It has been suggested that leaf variegation plays several physiological and ecological functions such as defense from enemies, adaptations to light, temperature, etc. [16-25]. We tested the hypothesis that leaf variegation plays a low temperature protective function in P. tobira, which is an ornamental shrub widely grown in temperate climate and therefore is annually subjected to cold stress. It is well known that increased activities of antioxidant enzymes such as POD, CAT, SOD under abiotic stress conditions including drought, salt, chilling, heat, etc., promote enhanced stress tolerance in plants [44]. Our results demonstrated that "Variegatum" has much more efficient ROS-scavenging machinery compared to "Green Pittosporum" and accumulates less MDA, an indicator of limited cellular membrane damage due to lipid peroxidation. Hence, "Variegatum" better tolerates low temperature stress than "Green Pittosporum" (Figure 4). We further sequenced the transcriptomes of both leaf types under cold condition $\left(10^{\circ} \mathrm{C}\right)$. Differential gene expression (DEG) analysis resulted in 309 DEGs between the two cultivars, enriched in biological pathways related to the biosynthesis of unsaturated fatty acids, sesquiterpenoid and triterpenoid biosynthesis, fatty acid metabolism, phenylalanine metabolism and protein processing in endoplasmic reticulum, which may be crucial pathways involved in cold stress alleviation (Figure 6).

Cell membrane structure, integrity and fluidity are affected by lipid composition and the degree of fatty acid (FA) desaturation in plants [45]. It has been documented that changes in unsaturated fatty acids content can improve plant tolerance to environmental stresses such as cold, heat and drought [46-51], since modification of membrane fluidity results in an environment suitable for the function of critical integral proteins, such as the photosynthetic machinery, during stresses [52]. In this study, we detected ten FAD2 genes all significantly up-regulated in "Variegatum" leaves under cold condition (Table 5). The microsomal enzyme FAD2 principally acts on the desaturation of C18:1 (monounsaturated FA) to C18:2 (polyunsaturated FA) [53], suggesting that "Variegatum" tends to increase polyunsaturated FA (PUFA) level, a mechanism to maintain cell membrane fluidity under low temperature [54,55]. This skill of adjusting membrane fluidity by varying the unsaturated fatty acid content is characteristic of cold-responsive plants [52]. Cold acclimating potato (Solanum commersonii) was found to accumulate linoleic acid (18:2) in the membrane glycerolipids of the leaves, whereas commercial, non-acclimating potato (Solanum tuberosum) did not show this trait during cold stress [56]. Our findings are in perfect accordance with reports of Liu et al. [51], who showed that over-expression of 
tomato FAD2 gene alleviates the photoinhibition of photosystems 2 and 1 and improves tolerance under chilling stress. Similar observations were reported in various plants such as cotton [57], A. thaliana [58], Olea europaea [59], Synechocystis sp. [60], etc., under low temperature conditions.

Membrane fatty acid composition is, to a great extent, determined by the activities of complexly regulated integral fatty acid desaturases and lipases [52]. GDSL-lipase participates in fatty acid catabolism and studies have shown that the linoleic acid and other PUFAs contents are significantly decreased when GDSL genes are over-expressed [61-64]. Here, we detected nine GDSL-lipase genes all down-regulated in "Variegatum" under low temperature stress (Table 5), denoting a strategy to keep the high level of PUFA for the maintenance of cell membrane stability. We deduce that down-regulation of GDSL genes and up-regulation of FAD2 genes is therefore an integrated and efficient mechanism to cope with cold stress in P. tobira cv. "Variegatum".

Another group of genes detected within the DEGs between "Variegatum" and "Green Pittosporum" under cold condition are heat shock proteins (HSP) (Table 5). HSPs are molecular chaperones that are constantly present in cells to correctly fold proteins involved in routine cellular processes such as translocation, cell-signaling and metabolism [65]. However, HSPs become abundant in most organisms in response to protein denaturation caused by environmental, metabolic and pathological stresses [66]. For example, Arabidopsis, grape, rice, Brassicas increase the production of HSPs to augment survival in cold environments [67-70]. On the other hand, it was reported that a complex coordination of HSPs underlines cold tolerance in plants [65]. In fact, some HSPs are either up- or down-regulated when heat shock factors (HSFs) bind to their promoter regions [71,72]. This suggests that not all HSPs positively participate in cold or stress tolerance in plants. Each group of these HSPs has a unique mechanism [65]. In our study, we observed that small HSPs were all down-regulated while high molecular weight HSP genes were up-regulated in "Variegatum", pointing out an opposite function of HSPs for cold response in P. tobira with respect to their molecular weights. For now, a clear explanation for this phenomenon is yet to be found, hence, an in-depth investigation of the role of HSP genes and their relation with the significantly altered HSF transcription factors under cold condition in P. tobira is necessary in order to clarify this intriguing finding.

Our transcriptome analysis also unveiled several peroxidase genes from the phenyalanine pathway as well as some cytochrome P450 genes from the sesquiterpenoid and triterpenoid biosynthesis as candidate genes, which positively contribute to the enhanced cold responses in "Variegatum" (Table 5). Peroxidase genes have been extensively studied in plants for their ROS-scavenging activity under various biotic and abiotic stresses, including chilling [73-75]. Similarly, Liu et al. [76] recently investigated the prominent biological pathways engaged in wild banana tolerance to chilling. They observed significant changes in the sesquiterpenoid and triterpenoid biosynthesis, particularly cytochrome $P 450$ genes, a finding that supports well the results of our study.

Taken together, we showed that leaf variegation in P. tobira is associated to defected chloroplast development, reduced chlorophyll content, high content of carotenoids and a high level of ROS. The results of transcriptome analysis were consistent with the enzymatic activity under cold conditions. These results pointed out that the leaf variegation trait plays low temperature protective effect in P. tobira by inducing a strong ROS-scavenging activity through catalase and peroxidase enzymes, inducing heat shock proteins for cellular homeostasis and, more importantly, by maintaining high levels of PUFA for cell membrane stability and fluidity through a coordinated up-regulation of FAD2 and down-regulation of GDSL-lipase genes. The modulation of the expression levels of these key genes may be orchestrated by transcription factors from the families of NAC, WRKY, HSF and AP2/ERF. A proposed schematic model for the stronger cold response in "Variegatum" is summarized in Figure 8. 


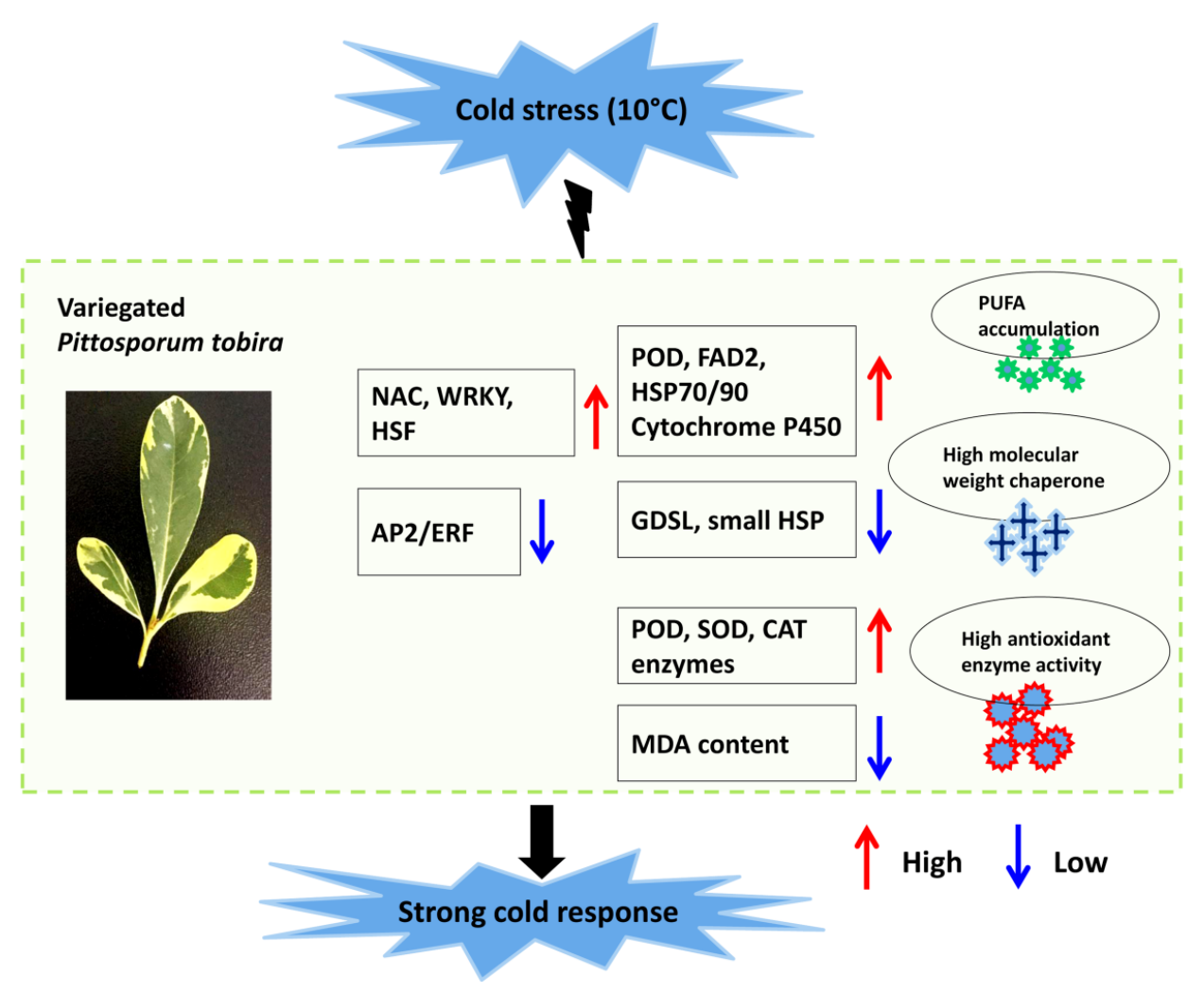

Figure 8. A schematic model of the proposed mechanism underlying the strong cold response in $P$. tobira cv. "Variegatum".

\section{Materials and Methods}

\subsection{Plant Materials}

The naturally occurring variegated cultivar of Pittosporum tobira "Variegatum" and the widely grown cultivar "Green Pittosporum" were originally collected from Pingdingshan, Henan in China and used as experimental materials. Biochemical data were recorded on three different plants of each cultivar at different dates corresponding to various temperature gradients $\left(20-10^{\circ} \mathrm{C}\right)$ from August to November (Figure 1).

\subsection{Transmission Electron Microscopy (TEM)}

TEM analysis was performed as described by Shih et al. [3]. Green and yellow sectors of leaves were cut into small cubes in the field and placed in a fixation solution containing $2.5 \%$ glutaraldehyde and $4 \%$ paraformaldehyde in $0.1 \mathrm{M}$ sodium phosphate buffer (pH 7.0). Samples underwent $20 \mathrm{~min}$ of rinsing three times and were post-fixed in $1 \%$ osmium tetroxide for $2 \mathrm{~h}$. After being dehydrated through an ethanol series, samples were infiltrated and embedded in Spurr's resin and then polymerized at $70^{\circ} \mathrm{C}$ for $8 \mathrm{~h}$. Ultrathin sections $(\sim 70-90 \mathrm{~nm})$ were collected and stained with ethanol uranyl acetate and lead citrate. The morphology of plastids was observed with Tecnai F20S TEM (The Thermo Scientific ${ }^{\mathrm{TM}}$, Waltham, MA, USA) at $200 \mathrm{kV}$.

\subsection{Measurement of Physio-Biochemical Parameters}

A total of $50 \mathrm{mg}$ fresh leaves were used to extract chlorophyll. The total chlorophyll content (ChlT, $\left.\mathrm{mg} \mathrm{g}^{-1} \mathrm{FW}\right)$ and carotenoids content $\left(\mathrm{Ca}, \mathrm{mg} \mathrm{g}^{-1} \mathrm{FW}\right)$ were determined as described by Wellburn [77]. The net photosynthetic rate $\left(P n, \mu \mathrm{mol} \mathrm{m}{ }^{-2} \mathrm{~s}^{-1}\right)$, intercellular $\mathrm{CO}_{2}$ concentration (Ci/ppm) and transpiration rate $\left(\mathrm{Tr}, \mathrm{mmol} . \mathrm{m}^{-2} \mathrm{~s}^{-1}\right)$ were determined with a portable L-6400XT (LI-COR, Lincoln, NB, USA). The measurements of photosynthetic parameters were taken at the 
saturation irradiance with an incident photosynthetic photo flux density (PPFD) of $1200 \mu \mathrm{mo} \mathrm{m}^{-2} \mathrm{~s}^{-1}$ and an airflow rate at $500 \mu \mathrm{mol} \mathrm{s}^{-1}$. The enzymatic activities of superoxide dismutase (SOD, $\mathrm{U} \mathrm{g}^{-1}$ ), catalase (CAT, $\mathrm{U} \mathrm{g}^{-1} \cdot \mathrm{min}^{-1}$ ), peroxidase (POD, $\mathrm{U} \mathrm{g}^{-1} \cdot \mathrm{min}^{-1}$ ) and the content of malonaldehyde (MDA, $\mu \mathrm{mol} \mathrm{g}^{-1}$ ) were calculated by following the manufacturer's instructions (Biological Engineering Institute of Nanjing Jiancheng, China). Means from three replicates were used for statistical analysis.

\subsection{RNA Extraction, cDNA Library Construction, and Transcriptome Sequencing}

The complete leaves from the cultivars "Green Pittosporum" and "Variegatum" were collected in replicates from three different plants under cold conditions at November $15^{\text {th }}$ (Temperature $=10^{\circ} \mathrm{C}$ ), immediately frozen in liquid nitrogen and stored at $-80^{\circ} \mathrm{C}$ until further use. Total RNAs were extracted using Spin Column Plant total RNA Purification Kit following the manufacturer's protocol (Sangon Biotech, Shanghai, China). Purity of the extracted RNAs was assessed on $1 \%$ agarose gels followed by NanoPhotometer spectrophotometer (IMPLEN, Los Angeles, CA, USA). We quantified the RNA using Qubit RNA Assay Kit in Qubit 2.0 Flurometer (Life Technologies, Carlsbad, CA, USA). RNA integrity was checked using the RNA Nano 6000 Assay Kit of the Agilent Bioanalyzer 2100 system (Agilent Technologies, Santa Clara, CA, USA).

Libraries preparation, and sequencing on Illumina HiSeq 4000 platform (Illumina Inc., San Diego, CA, USA) were performed as described by Zhuang et al. [78].

\subsection{De novo Assembly, Functional Annotation, Classification and Metabolic Pathway Analysis}

Raw transcriptome data were submitted to NCBI SRA, freely accessible at www.ncbi.nlm.nih. gov/bioproject/PRJNA553027. The clean reads were retrieved after trimming adapter sequences, removal of low quality (containing $>50 \%$ bases with a Phred quality score $<15$ ) and reads with unknown nucleotides (more than 1\% ambiguous residues N) using the FastQC tool (http://www. bioinformatics.babraham.ac.uk/projects/fastqc/). The high-quality reads from all the six libraries were de novo assembled into transcripts using Trinity (Version r20140717) [79] by employing paired-end method. Next, the transcripts were realigned to construct unigenes. The assembled unigenes were then annotated by searching against various databases such as Kyoto Encyclopedia of Genes and Genomes (KEGG) [80], Gene Ontology (GO) [81], Clusters of Orthologous Groups (COG) [82], Pfam [83], Swissprot [84], egNOG [85], NR [86], euKaryotic Orthologous Groups (KOG) [87] using BLAST [88] with a threshold of E-value $<1.0 \mathrm{E}^{-5}$.

The software KOBAS2.0 [89] was employed to get the unigene KEGG orthology; the analogs of the unigene amino acid sequences were searched against the Pfam database [83] using HMMER tool [90] with a threshold of E-value $<1.0 \mathrm{E}^{-10}$. The sequenced reads were compared with the unigene library using Bowtie [91], and the level of expression was estimated in combination with RSEM [92]. The gene expression level was determined according to the fragments per kilobase of exon per million fragments mapped (FPKM).

\subsection{Differential Expression and Enrichment Analysis}

The read count was normalized and EdgeR Bioconductor package [93] was used to determine the differential expressed genes (DEGs) between the two cultivars with the fold change of $>2$ [94] and false discovery rate correction (FDR) set at $p<0.01$. GO enrichment analysis was performed using the topGO method [95] based on the wallenius non-central hypergeometric distribution with $p<0.05$. KEGG pathway enrichment analysis of the DEGs was done using KOBAS2.0 [89]. The FDR correction was employed $(p<0.05)$ to reduce false positive prediction of enriched KEGG pathways.

\subsection{Validation of Gene Expression Using Quantitative Real Time-PCR}

The qRT-PCR was performed on RNA extracted from leaf samples of "Variegatum" and "Green Pittosporum" as described by Dossa et al. [96] using the Actin gene as the internal control. Specific 
primer pairs of ten selected genes were designed using the Primer Premier 5.0 [97] (Table S3). Data are presented as relative transcript level based on the $2^{-\Delta \Delta C t}$ method [98].

\subsection{Statistical Analysis}

Data were analyzed with the R software (www.r-project.org) using the one-way analysis of variance (ANOVA) for significant difference. The error bars were calculated with data from three replicates. ANOVA results were considered significant at $p<0.05$ and mean comparisons were done using the Tukey HSD test.

Supplementary Materials: Supplementary Materials can be found at http://www.mdpi.com/1422-0067/20/19/ 4857/s1. Table S1. Full list of the unigenes annotated in Pittosporum tobira leaf; Table S2. Full list of the genes expressed in Pittosporum tobira leaf and their FPKM values. T01-T03 represent the three replicates libraries of the cultivar "Green Pittosporum" and T04-T06 represent the three replicates libraries of the cultivar "Variegatum"; Table S3. The primer sequences of genes used for real time quantitative PCR; Figure S1. qRT-PCR results of 10 selected genes and correlation between transcriptome data and real time PCR results.

Author Contributions: Z.Z. project design and paper writing; Z.L. Data processing and analysis; H.S. experimental test and data analysis; M.C. experimental test and data collection; S.C. project design and management. All authors have read and approved the final version of this manuscript.

Funding: This research was funded by the Project of Henan Science and Technology Research Program (Agricultural Field), grant number: 162120110070.

Conflicts of Interest: The authors declare no conflict of interest.

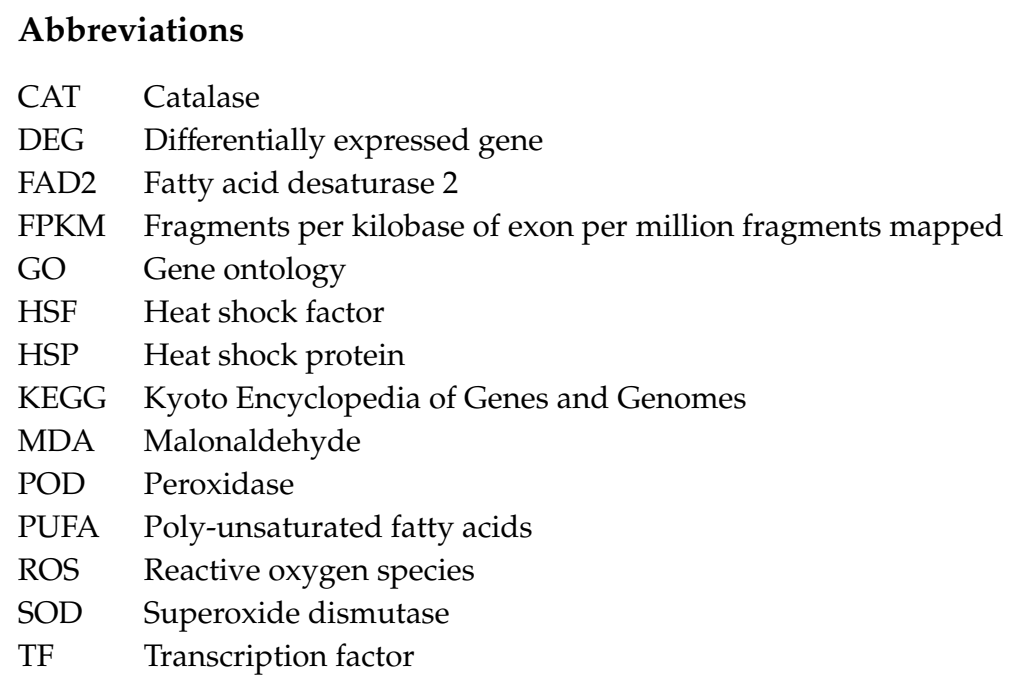

\section{References}

1. Aluru, M.R.; Bae, H.; Wu, D.; Rodermel, S.R. The Arabidopsis immutans mutation affects plastid differentiation and the morphogenesis of white and green sectors in variegated plants. Plant Physiol. 2001, 127, 67-77. [CrossRef] [PubMed]

2. Kato, Y.; Kouso, T.; Sakamoto, W. Variegated tobacco leaves generated by chloroplast FtsH suppression: Implication of FtsH function in the maintenance of thylakoid membranes. Plant Cell Physiol. 2012, 53, 391-404. [CrossRef] [PubMed]

3. Shih, T.-H.; Lin, S.-H.; Huang, M.-Y.; Huang, W.-D.; Yang, C.-M. Transcriptome profile of the variegated Ficus microcarpa c.v. milkys fig leaf. Int. J. Mol. Sci. 2019, 20, 1338. [CrossRef] [PubMed]

4. Tsai, C.C.; Wu, Y.J.; Sheue, C.R.; Liao, P.C.; Chen, Y.H.; Li, S.J.; Liu, J.W.; Chang, H.T.; Liu, W.L.; Ko, Y.Z.; et al. Molecular basis underlying leaf variegation of a moth orchid mutant (Phalaenopsis aphrodite subsp. formosana). Front. Plant Sci. 2017, 8, 1333. [CrossRef] [PubMed]

5. Hara, N. Study of the variegated leaves with special reference to those caused by air spaces. Jpn. J. Bot. 1957, $16,86-101$. 
6. Sheue, C.R.; Pao, S.H.; Chien, L.F.; Chesson, P.; Peng, C.I. Natural foliar variegation without costs? The case of Begonia. Ann. Bot. 2012, 109, 1065-1074. [CrossRef] [PubMed]

7. Tsukaya, H.; Okada, H.; Mohamed, M. A novel feature of structural variegation in leaves of the tropical plant Schismatoglottis calyptrata. J. Plant Res. 2004, 117, 477-480. [CrossRef]

8. Tilney-Bassett, R.A.E. Genetics of variegated plants. In Genetics and Biogenesis of Mitochondria and Chloroplasts; Birky, C.W., Perlman, P.S., Byers, T.J., Eds.; Ohio State University Press: Columbus, OH, USA, 1975; pp. 268-308.

9. Beardsell, D.; Norden, U. Ficus rubiginosa 'variegata', a chlorophyll-deficient chimera with mosaic patterns created by cell divisions from the outer meristematic layer. Ann. Bot. 2004, 94, 51-58. [CrossRef]

10. Yu, F.; Fu, A.; Aluru, M.; Park, S.; Xu, Y.; Liu, H.; Liu, X.; Foudree, A.; Nambogga, M.; Rodermel, S. Variegation mutants and mechanisms of chloroplast biogenesis. Plant Cell Environ. 2007, 30, 350-365. [CrossRef]

11. Li, X.; Kanakala, S.; He, Y.; Zhong, X.; Yu, S.; Li, R.; Sun, L.; Ma, J. Physiological characterization and comparative transcriptome analysis of white and green leaves of Ananas comosus var. bracteatus. PLoS ONE 2017, 12, e0169838. [CrossRef]

12. Lysenko, V. Fluorescence kinetic parameters and cyclic electron transport in guard cell chloroplasts of chlorophyll-deficient leaf tissues from variegated weeping fig (Ficus benjamina L.). Planta 2012, 235, 1023-1033. [CrossRef] [PubMed]

13. Aluru, M.R.; Zola, J.; Foudree, A.; Rodermel, S.R. Chloroplast photooxidation-induced transcriptome reprogramming in Arabidopsis immutans white leaf sectors. Plant Physiol. 2009, 150, 904-923. [CrossRef] [PubMed]

14. Miura, E.; Kato, Y.; Sakamoto, W. Comparative transcriptome analysis of green/white variegated sectors in Arabidopsis yellow variegated2: Responses to oxidative and other stresses in white sectors. J. Exp. Bot. 2010, 61, 2433-2445. [CrossRef] [PubMed]

15. Yang, Y.; Chen, X.; Xu, B.; Li, Y.; Ma, Y.; Wang, G. Phenotype and transcriptome analysis reveals chloroplast development and pigment biosynthesis together influenced the leaf color formation in mutants of Anthurium and raeanum 'Sonate'. Front. Plant Sci. 2015, 6, 139. [CrossRef] [PubMed]

16. Lev-Yadun, S.; Dafni, A.; Flaishman, M.A.; Inbar, M.; Izhaki, I.; Katzir, G.; Ne'eman, G. Plant coloration undermines herbivorous insect camouflage. BioEssays 2004, 26, 1126-1130. [CrossRef] [PubMed]

17. Lev-Yadun, S. Defensive (anti-herbivory) coloration in land plants. In Anti-Herbivory Plant Coloration and Morphology; Springer: Zug, Switzerland, 2016.

18. Lev-Yadun, S. Local loss of the zebra-like coloration supports the aposematic and other visual defense hypotheses in Silybum marianum. Isr. J. Plant Sci. 2017, 64, 170-178. [CrossRef]

19. Niu, Y.; Sun, H.; Stevens, M. Plant camouflage: Ecology, evolution, and implications. Trends Ecol. Evol. 2018, 33, 608-618. [CrossRef]

20. Fooshee, W.C.; Henny, R.J. Chlorophyll levels and anatomy of variegated and non variegated areas of Aglaonema nitidum leaves. Proc. Fla. State Hortic. Soc. 1990, 103, 170-172.

21. Roelfsema, M.; Konrad, K.R.; Marten, H.; Psaras, G.K.; Hartung, W.; Hedrich, R. Guard cells in albino leaf patches do not respond to photosynthetically active radiation, but are sensitive to blue light, $\mathrm{CO}_{2}$ and abscisic acid. Plant Cell Environ. 2006, 29, 1595-1605. [CrossRef]

22. Shelef, O.; Summerfield, L.; Lev-Yadun, S.; Villamarin-Cortez, S.; Sadeh, R.; Herrmann, I.; Rachmilevitch, S. Thermal benefits from white variegation of Silybum marianum Leaves. Front. Plant Sci. 2019, 10, 688. [CrossRef]

23. Smith, A.P. Ecology of a leaf color polymorphism in a tropical forest species: Habitat segregation and herbivory. Oecologia 1986, 69, 283-287. [CrossRef] [PubMed]

24. Soltau, U.; Dötterl, S.; Liede-Schumann, S. Leaf variegation in Caladium steudneriifolium (Araceae): A case of mimicry? Evol. Ecol. 2009, 23, 503-512. [CrossRef]

25. Mwafongo, E.; Vollsnesb, A.V.; Bjorå, C.S.; Nordal, I.; Eriksen, A.B. Leaf mottling/variegation and shape in the Ledebouria revoluta complex-Development, stability and putative function. Flora 2017, 236, 33-43. [CrossRef]

26. Dib, R.A.E.; Eskander, J.; Mohamed, M.A.; Mohammed, N.M. Two new triterpenoid estersaponins and biological activities of Pittosporum tobira, 'variegata' (Thunb.) WT. Aiton leaves. Fitoterapia 2015, 106, $272-279$. [CrossRef] 
27. Burt, S. Essential oils: Their antibacterial properties and potential applications in foods-a review. Int. J. Food Microbiol. 2004, 94, 223-253. [CrossRef]

28. Eunsil, K.O.; Choi, M.R.; Choi, K.M.; Cha, J.D. The effect of Pittosporum tobira against anti-Helicobacter pylori and anti-oxidant activity. IJVR 2014, 8, 4 .

29. Jiang, H.; Chen, Y.; Li, M.; Xu, X.; Wu, G. Overexpression of SGR results in oxidative stress and lesion-mimic cell death in rice seedlings. J. Integr. Plant Biol. 2011, 53, 375-387. [CrossRef]

30. Han, S.H.; Sakuraba, Y.; Koh, H.J.; Paek, N.C. Leaf variegation in the rice zebra2 mutant is caused by photoperiodic accumulation of tetra-Cis-lycopene and singlet oxygen. Mol. Cells 2012, 33, 87-97. [CrossRef]

31. Sheoran, S.; Thakur, V.; Narwal, S.; Turan, R.; Mamrutha, H.M.; Singh, V.; Tiwari, V.; Sharma, I. Differential activity and expression profile of antioxidant enzymes and physiological changes in wheat (Triticum aestivum L.) under drought. Appl. Biochem. Biotechnol. 2015, 177, 1282-1298. [CrossRef]

32. Esteban, R.; Fernandez-Marin, B.; Becerril, J.M.; Garcia-Plazaola, J.I. Photoprotective implications of leaf variegation in E. denscanis L. and P. officinalis L. J. Plant Physiol. 2007, 165, 1255-1263. [CrossRef]

33. Sui, N.; Li, M.; Zhao, S.J.; Li, F.; Liang, H.; Meng, Q.W. Overexpression of glycerol-3-phosphate acyltransferase gene improves chilling tolerance in tomato. Planta 2007, 226, 1097-1108. [CrossRef] [PubMed]

34. Kim, S.-H.; Kwon, C.-T.; Song, G.; Koh, H.-G.; An, G.; Paek, N.-C. The rice zebra3 (z3) mutation disrupts citrate distribution and produces transverse dark-green/green variegation in mature leaves. Rice 2018, 11, 1. [CrossRef] [PubMed]

35. Wetzel, C.M.; Jiang, C.Z.; Meehan, L.J.; Voytas, D.F.; Rodermel, S.R. Nuclear-organelle interactions: The immutans variegation mutant of Arabidopsis is plastid autonomous and impaired in carotenoid biosynthesis. Plant J. 1994, 6, 161-175. [CrossRef] [PubMed]

36. Miura, E.; Kato, Y.; Matsushima, R.; Albrecht, V.; Laalami, S.; Sakamoto, W. The balance between protein synthesis and degradation in chloroplasts determines leaf variegation in Arabidopsis yellow variegated mutants. Plant Cell 2007, 19, 1313-1328. [CrossRef] [PubMed]

37. Bae, C.H.; Abe, T.; Matsuyama, T.; Fukunishi, N.; Nagata, N.; Nakano, T.; Kaneko, Y.; Miyoshi, K.; Matsushima, H.; Yoshida, S. Regulation of chloroplast gene expression is affected in ali, a novel tobacco albino mutant. Ann. Bot. 2001, 88, 545-553. [CrossRef]

38. Aluru, M.R.; Yu, F.; Fu, A.; Rodermel, S. Arabidopsis variegation mutants: New insights into chloroplast biogenesis. J. Exp. Bot. 2006, 57, 1871-1881. [CrossRef] [PubMed]

39. Sun, Y.-H.; Hung, C.-Y.; Qiu, J.; Chen, J.; Kittur, F.S.; Oldham, C.E.; Henny, R.J.; Burkey, K.O.; Fan, L.; Xie, J. Accumulation of high OPDA level correlates with reduced ROS and elevated GSH benefiting white cell survival in variegated leaves. Sci. Rep. 2017, 7, 44158. [CrossRef]

40. Klančnik, K.; Levpušček, M.; Gaberščik, A. Variegation and red abaxial epidermis define the leaf optical properties of Cyclamen purpurascens. Flora 2016, 224, 87-95. [CrossRef]

41. Zhang, Q.; Zhang, M.; Ding, Y.; Zhou, P.; Fang, Y. Composition of photosynthetic pigments and photosynthetic characteristics in green and yellow sectors of the variegated Aucuba japonica Variegata leaves. Flora 2018, 240, 25-33. [CrossRef]

42. Borek, M.; Baczek-Kwinta, R.; Rapacz, M. Photosynthetic activity of variegated leaves of Coleus $\mathrm{x}$ hybridus hort. cultivars characterised by chlorophyll fluorescence techniques. Photosynthetica 2016, 54, 331-339. [CrossRef]

43. Hashimoto, H.; Uragami, C.; Cogdell, R.J. Carotenoids and Photosynthesis. In Carotenoids in Nature; Subcellular Biochemistry; Stange, C., Ed.; Springer: Cham, Switzerland, 2016; Volume 79. [CrossRef]

44. Farooq, M.; Hussain, M.; Wahid, A.; Siddique, K.H.M. Drought stress in plants: An overview. In Plant Responses to Drought Stress: From Morphological to Molecular Features; Aroca, R., Ed.; Springer: Berlin/Heidelberg, Germany, 2012; pp. 1-33.

45. Mikami, K.; Murata, N. Membrane fluidity and the perception of environmental signals in cyanobacteria and plants. Prog. Lipid Res. 2003, 42, 527-543. [CrossRef]

46. Dakhma, W.S.; Zarrouk, M.; Cherif, A. Effects of drought stress on lipids in rape leaves. Phytochemistry 1995, 40, 1383-1386. [CrossRef]

47. Olsson, M. Alteration in lipid-composition, lipid-peroxidation and antioxidative protection during senescence in drought stressed plants of Pisum sativum. Plant Physiol. Biochem. 1995, 33, 547-553. 
48. Matos, M.C.; Campos, P.S.; Ramalho, J.C.; Medeira, M.C.; Maia, M.I.; Semedo, J.M.; Marques, N.M.; Matos, A. Photosynthetic activity and cellular integrity of the Andean legume Pachyrhizus ahipa (Wedd.) Parodi under heat and water stress. Photosynthetica 2002, 40, 493-501. [CrossRef]

49. Sui, N.; Li, M.; Shu, D.F.; Zhao, S.J.; Meng, Q.W. Antisense mediated depletion of tomato chloroplast glycerol-3- phosphate acyltransferase affects male fertility and increases thermal tolerance. Physiol. Plant. 2007, 130, 301-314. [CrossRef]

50. Sui, N.; Li, M.; Li, K.; Song, J.; Wang, B.-S. Increase in unsaturated fatty acids in membrane lipids of Suaeda salsa L. enhances protection of photosystem II under high salinity. Photosynthetica 2010, 48, 623-629. [CrossRef]

51. Liu, X.-Y.; Li, B.; Yang, J.-H.; Sui, N.; Yang, X.-M.; Meng, Q.-W. Overexpression of tomato chloroplast omega-3 fatty acid desaturase gene alleviates the photoinhibition of photosystems 2 and 1 under chilling stress. Photosynthetica 2008, 46, 185-192. [CrossRef]

52. Upchurch, R.G. Fatty acid unsaturation, mobilization, and regulation in the response of plants to stress. Biotechnol. Lett. 2008, 30, 967-977. [CrossRef] [PubMed]

53. Dar, A.; Choudhury, A.R.; Kancharla, P.K.; Arumugam, N. The FAD2 gene in plants: Occurrence, regulation, and role. Front. Plant Sci. 2017, 8, 1789. [CrossRef] [PubMed]

54. Los, D.A.; Murata, N. Structure and expression of fatty acid desaturases. Biochem. Biophys. Acta 1998, 1394, 3-15. [CrossRef]

55. Routaboul, J.M.; Fischer, S.F.; Browse, J. Trienoic fatty acids are required to maintain chloroplast function at low temperatures. Plant Physiol. 2000, 124, 1697-1705. [CrossRef] [PubMed]

56. Vega, S.E.; del Rio, A.H.; Bamberg, J.B.; Palta, J.P. Evidence for the up-regulation of stearoyl-ACP (D9) desaturase gene expression during cold acclimation. Am. J. Potato Res. 2004, 81, 125-135. [CrossRef]

57. Kargiotidou, A.; Deli, D.; Galanopoulou, D.; Tsaftaris, A.; Farmaki, T. Low temperature and light regulate delta 12 fatty acid desaturases (FAD2) at a transcriptional level in cotton (Gossypium hirsutum). J. Exp. Bot. 2008, 59, 2043-2056. [CrossRef] [PubMed]

58. Kreps, J.A.; Wu, Y.; Chang, H.S.; Zhu, T.; Wang, X.; Harper, J.F. Transcriptome changes for Arabidopsis in response to salt, osmotic, and cold stress. Plant Physiol. 2002, 130, 129-2141. [CrossRef] [PubMed]

59. Matteucci, M.; D’Angeli, S.; Errico, S.; Lamanna, R.; Perrotta, G.; Altamura, M.M. Cold affects the transcription of fatty acid desaturases and oil quality in the fruit of Olea europaea L. genotypes with different cold hardiness. J. Exp. Bot. 2011, 62, 3403-3420. [CrossRef] [PubMed]

60. Los, D.A.; Ray, M.K.; Murata, N. Differences in the control of the temperature-dependent expression of four genes for desaturases in Synechocystis sp. PCC 6803. Mol. Microbiol. 1997, 25, 1167-1175. [CrossRef] [PubMed]

61. Huang, L.M.; Lai, C.P.; Chen LF, O.; Chan, M.T.; Shaw, J.F. Arabidopsis SFAR4 is a novel GDSL-type esterase involved in fatty acid degradation and glucose tolerance. Botani Stud. 2015, 56, 33. [CrossRef]

62. Xu, H.M.; Kong, X.D.; Chen, F.; Huang, J.X.; Lou, X.Y.; Zhao, J.Y. Transcriptome analysis of Brassica napus pod using RNA-Seq and identification of lipid-related candidate genes. BMC Genom. 2015, 16, 858. [CrossRef]

63. Duan, S.; Jin, C.; Li, D.; Gao, C.; Qi, S.; Liu, K.; Hai, J.; Ma, H.; Chen, M. MYB76 inhibits seed fatty acid accumulation in Arabidopsis. Front. Plant Sci. 2017, 8, 226. [CrossRef]

64. Zhang, Y.; Bai, B.; Lee, M.; Alfiko, Y.; Suwanto, A.; Yue, G.H. Cloning and characterization of EgGDSL, a gene associated with oil content in oil palm. Sci. Rep. 2018, 8, 11406. [CrossRef]

65. Al-Whaibi, M.H. Plant heat-shock proteins: A mini review. J. King Saud Univ. Sci. 2011, 23, $139-150$. [CrossRef]

66. Vierling, E. The Roles of Heat Shock Proteins in Plants. Ann. Rev. Plant Physiol. Plant Mol. Biol. 1991, 42, 579-620. [CrossRef]

67. Krishna, P.; Sacco, M.; Cherutti, J.F.; Hill, S. Cold induced accumulation of Hsp90 transcripts in Brassica napus. Plant Physiol. 1995, 107, 915-923. [CrossRef] [PubMed]

68. Pareek, A.; Singla, S.L.; Grover, A. Plant Hsp90 family with special reference to rice. J. Biosci. 1998, 23, 361-367. [CrossRef]

69. Kilian, J.; Whitehead, D.; Horak, J.; Wanke, D.; Weinl, S.; Batistic, O.; Bauer, E.B.; D’Angelo; Kudla, J.; Harter, K. The AtGenExpress global stress expression data set: Protocols, evaluation and model data analysis of UV-B light, drought and cold stress responses. Plant J. 2007, 50, 347-363. [CrossRef] 
70. Zhang, J.-H.; Wang, L.-J.; Pan, Q.-H.; Wang, Y.-Z.; Zhan, J.-C.; Huang, W.-D. Accumulation and subcellular localization of heat shock proteins in young grape leaves during cross-adaptation to temperature stresses. Sci. Hortic. 2008, 117, 231-240. [CrossRef]

71. Baniwal, S.K.; Bharti, K.; Chan, K.Y.; Fauth, M.; Ganguli, A.; Kotak, S.; Mishra, S.K.; Nover, L.; Port, M.; Scharf, K.; et al. Heat stress response in plants: A complex game with chaperones and more than 20 heat stress transcription factors. J. Biosci. 2004, 29, 471-487. [CrossRef]

72. Hu, W.; Hu, G.; Han, B. Genome-wide survey and expression profiling of heat shock proteins and heat shock factors revealed overlapped and stress specific response under abiotic stresses in rice. Plant Sci. 2009, 176, 583-590. [CrossRef]

73. Gao, C.; Wang, Y.; Liu, G.; Wang, C.; Jiang, J.; Yang, C. Cloning of ten peroxidase (POD) genes from Tamarix hispida and characterization of their responses to abiotic stress. Plant Mol. Biol. Report. 2010, 28, 77. [CrossRef]

74. Kim, S.-H.; Choi, H.-S.; Cho, Y.-C.; Kim, S.-R. Cold-responsive regulation of a flower-preferential class III peroxidase gene, OsPOX1, in rice (Oryza sativa L.). J. Plant Biol. 2012, 55, 123-131. [CrossRef]

75. Wang, J.-E.; Liu, K.-K.; Li, D.-W.; Zhang, Y.-L.; Zhao, Q.; He, Y.-M.; Gong, Z.-H. A Novel Peroxidase CanPOD Gene of Pepper Is Involved in Defense Responses to Phytophtora capsici Infection as well as Abiotic Stress Tolerance. Int. J. Mol. Sci. 2013, 14, 3158-3177. [CrossRef] [PubMed]

76. Liu, W.; Cheng, C.; Chen, F.; Ni, S.; Lin, Y.; Lai, Z. High-throughput sequencing of small RNAs revealed the diversified cold-responsive pathways during cold stress in the wild banana (Musa itinerans). BMC Plant Biol. 2018, 18, 308. [CrossRef] [PubMed]

77. Wellburn, A.R. The spectral determination of chlorophylls a and $b$, as well as total carotenoids, using various solvents with spectrophotometers of different resolution. J. Plant Physiol. 1994, 144, 307-313. [CrossRef]

78. Zhuang, H.; Lou, Q.; Liu, H.; Han, H.; Wang, Q.; Tang, Z.; Ma, Y.; Wang, H. Differential Regulation of Anthocyanins in Green and Purple Turnips Revealed by Combined De Novo Transcriptome and Metabolome Analysis. Int. J. Mol. Sci. 2019, 20, 4387. [CrossRef] [PubMed]

79. Grabherr, M.G.; Haas, B.J.; Yassour, M.; Levin, J.Z.; Thompson, D.A.; Amit, I.; Adiconis, X.; Fan, L.; Raychowdhury, R.; Zeng, Q.; et al. Full length transcriptome assembly from RNA Seq data without a reference genome. Nat. Biotechnol. 2011, 29, 644-652. [CrossRef] [PubMed]

80. Kanehisa, M.; Goto, S.; Kawashima, S.; Okuno, Y.; Hattori, M. The KEGG resource for deciphering the genome. Nucleic Acids Res. 2004, 32, D277-D280. [CrossRef] [PubMed]

81. Ashburner, M.; Ball, C.A.; Blake, J.A.; Botstein, D.; Butler, H.; Cherry, J.M.; Davis, A.P.; Dolinski, K.; Dwight, S.S.; Eppig, J.T.; et al. Gene ontology: Tool for the unification of biology. Nat. Genet. 2000, 25, $25-29$. [CrossRef]

82. Tatusov, R.L.; Galperin, M.Y.; Natale, D.A. The COG database: A tool for genome scale analysis of protein functions and evolution. Nucleic Acids Res. 2000, 28, 33-36. [CrossRef] [PubMed]

83. Finn, R.D.; Bateman, A.; Clements, J.; Coggill, P.; Eberhardt, R.Y.; Eddy, S.R.; Heger, A.; Hetherington, K.; Holm, L.; Mistry, J.; et al. Pfam: The protein families database. Nucleic Acids Res. 2013, 42, D222-D230. [CrossRef]

84. Apweiler, R.; Bairoch, A.; Wu, C.H.; Barker, W.C.; Boeckmann, B.; Ferro, S.; Gasteiger, E.; Huang, H.; Lopez, R.; Magrane, M.; et al. UniProt: The Universal Protein knowledgebase. Nucleic Acids Res. 2004, 32, D115-D119. [CrossRef]

85. Huerta-Cepas, J.; Szklarczyk, D.; Forslund, K.; Cook, H.; Heller, D.; Walter, M.C.; Rattei, T.; Mende, D.R.; Sunagawa, S.; Kuhn, M.; et al. eggNOG 4.5: A hierarchical orthology framework with improved functional annotations for eukaryotic, prokaryotic and viral sequences. Nucleic Acids Research 2015, 44, D286-D293. [CrossRef] [PubMed]

86. Deng, Y.Y.; Li, J.Q.; Wu, S.F.; Zhu, Y.; Chen, Y.W.; He, F.C. Integrated nr Database in Protein Annotation System and Its Localization. Comput. Eng. 2006, 32, 71-74.

87. Koonin, E.V.; Fedorova, N.D.; Jackson, J.D.; Jacobs, A.R.; Krylov, D.M.; Makarova, K.S.; Mazumder, R.; Mekhedov, S.L.; Nikolskaya, A.N.; Rao, B.S.; et al. A comprehensive evolutionary classification of proteins encoded in complete eukaryotic genomes. Genome Biol. 2004, 5, R7. [CrossRef] [PubMed]

88. Altschul, S.F.; Madden, T.L.; Schäffer, A.A.; Zhang, J.; Zhang, Z.; Miller, W.; Lipman, D.J. Gapped BLAST and PSI BLAST: A New Generation of Protein Database Search Programs. Nucleic Acids Res. Ital. 1997, 25, 3389-3402. [CrossRef] [PubMed] 
89. Xie, C.; Mao, X.; Huang, J.; Ding, Y.; Wu, J.; Dong, S.; Kong, L.; Gao, G.; Li, C.; Wei, L. KOBAS 2.0: A web server for annotation and identification of enriched pathways and diseases. Nucleic Acids Res. 2011, 39, W316-W322. [CrossRef] [PubMed]

90. Eddy, S.R. Profile hidden Markov models. Bioinform. Ital. 1998, 14, 755-763.

91. Langmead, B.; Trapnell, C.; Pop, M.; Salzberg, S.L. Ultrafast and memory-efficient alignment of short DNA sequences to the human genome. Genome Biol. 2009, 10, R25. [CrossRef] [PubMed]

92. Li, B.; Colin, N.D. RSEM: Accurate transcript quantification from RNA Seq data with or without a reference genome. BMC Bioinform. 2011, 12, 323. [CrossRef]

93. Robinson, M.D.; McCarthy, D.J.; Smyth, G.K. edgeR: A Bioconductor package for differential expression analysis of digital gene expression data. Bioinformatics 2010, 26, 139-140. [CrossRef]

94. Anders, S.; McCarthy, D.J.; Chen, Y.; Okoniewski, M.; Smyth, G.K.; Huber, W.; Robinson, M.D. Count-based differential expression analysis of RNA sequencing data using R and Bioconductor. Nat. Protoc. 2013, 8 , 1765-1786. [CrossRef]

95. Alexa, A.; Rahnenfuhrer, J. topGO: Enrichment Analysis for Gene Ontology; R Package Version 2.18.0; 2010; Volume 2, p. 2010.

96. Dossa, K.; Li, D.J.; Yu, J.; Wang, L.; Zhang, Y.; You, J.; Zhou, R.; Mmadi, M.A.; Li, A.; Fonceka, D.; et al. The genetic basis of drought tolerance in the high oil crop Sesamum indicum. Plant Biotechnol. J. 2019, 1-16. [CrossRef] [PubMed]

97. Lalitha, S. Primer premier 5. Biotechnol. Softw Internet Rep. 2000, 1, 270-272. [CrossRef]

98. Livak, K.J.; Schmittgen, T.D. Analysis of relative gene expression data using real-time quantitative PCR and the $2^{-\Delta \Delta C T}$ method. Methods 2001, 25, 402-408. [CrossRef] [PubMed]

(C) 2019 by the authors. Licensee MDPI, Basel, Switzerland. This article is an open access article distributed under the terms and conditions of the Creative Commons Attribution (CC BY) license (http://creativecommons.org/licenses/by/4.0/). 